\title{
Rise in the number of notified human hantavirus infections since October 2011 in Baden-Württemberg, Germany
}

I Boone (ides.boone@rps.bwl.de) ${ }^{1,2}$, C Wagner-Wiening ${ }^{1}$, D Reil ${ }^{3}$, J Jacob ${ }^{3}$, U M Rosenfeld ${ }^{4}$, R G Ulrich ${ }^{4}$, D Lohr ${ }^{1}$, G Pfaff ${ }^{1}$

1. Baden-Württemberg State Health Office, Epidemiology and Health Reporting, Stuttgart, Germany

2. European Programme for Intervention Epidemiology Training (EPIET), European Centre for Disease Prevention and Control $(E C D C)$, Stockholm, Sweden

3. Julius Kühn-Institute, Federal Research Centre for Cultivated Plants, Institute for Plant Protection in Horticulture and Forestry, Münster, Germany

4. Friedrich-Loeffler-Institute, Federal Research Institute for Animal Health, Institute for Novel and Emerging Infectious Diseases, Greifswald - Insel Riems, Germany

Citation style for this article:

Boone I, Wagner-Wiening C, Reil D, Jacob J, Rosenfeld UM, Ulrich RG, Lohr D, Pfaff G. Rise in the number of notified human hantavirus infections since October 2011 in Baden-Württemberg, Germany. Euro Surveill. 2012;17(21):pii=20180. Available online: http://www.eurosurveillance.org/ViewArticle.aspx?Articleld=20180

From October 2011 to April 2012, 852 human hantavirus infections were notified in Germany, of which 580 $(68 \%)$ were in Baden-Württemberg. Case numbers started to rise earlier than they did before the previous outbreaks in 2007 and 2010, and are the largest ever reported in this state during October to April of any year. The early rise could be due to a beech mast year in 2011, followed by an early and massive reproduction of the reservoir bank vole populations during winter 2011 and spring 2012.

\section{Outbreak description}

From October 2011 to April 2012 (reporting weeks 40 2011 to week 17 2012, ending 27 April 2012), 852 cases of hantavirus infections meeting the national case definition [1,2] were notified in Germany (cumulative incidence: 1.04 per 100,000 population) [3]. Of these, 580 cases $(68 \%)$ originated in the southern federal state of Baden-Württemberg (cumulative incidence: 5.4 per 100,000 population) (Table). This count exceeds the number of cases observed during the months October to April that preceded the outbreaks in 2007 (172 cases) and in 2010 (327 cases) in the same state (Table). We report on this ongoing outbreak in BadenWürttemberg, taking into consideration cases notified from October 2011 to April 2012.

\section{Background}

Puumala virus is the predominant human pathogenic hantavirus species in western, central and northern Europe [4]. It is transmitted to humans by exposure to excreta of its rodent reservoir, bank voles (Myodes glareolus) [5]. After an incubation period of usually two to four weeks [6], typical clinical manifestations include a sudden onset with fever, headache, back pain and gastrointestinal symptoms. Renal involvement is prominent and manifests initially as oliguria and later as marked polyuria (nephropathia epidemica)
[7]. Only $30 \%$ of Puumala virus infections occur with typical clinical signs, resulting in high under-reporting [8]. There is currently no specific antiviral treatment [4]. Recommended prevention measures focus on the avoidance of exposure and inhalation of potentially contaminated dust [9].

In Germany, laboratory-confirmed cases of hantavirus infections have been notifiable since $2001[1,10]$. Between 2001 and 2011, the number of annual notifications ranged from 72 to 447, with a median of 235 , except for two outbreaks in 2007 (1,688 cases) and 2010 (2,107 cases) [11]. From November 2011 to February 2012, the Robert Koch Institute observed an increase in the number of cases notified in Germany compared with the mean in the same period in the five preceding years, from $2006 / 2007$ to $2010 / 2011$. Some $64 \%$ of these cases were reported from Baden-Württemberg [11].

Figure 1 represents the temporal distribution of cases in Baden-Württemberg from reporting week 40 in 2011 until reporting week 17 in April 2012, in comparison with the outbreak periods of 2006-2007 and 20092010. The current outbreak period 2011-2012 is characterised by an early increase of cases, which started already in October 2011. In the last reported week in 2012 (week 17), the number of cases $(n=87)$ has almost reached the historical weekly maximum of the 2007 outbreak year (96 cases in week 22).

Figure 2 shows the geographical distribution of cases in Baden-Württemberg. Some $45 \%$ of all cases $(n=580)$ were reported from five of the 44 counties of BadenWürttemberg. These counties are in the central part of the state, comprising the city of Stutgart $(n=65$; incidence: 10.7 per 100,000 population), Tübingen ( $n=34$; incidence: 15.4 per 100,000 population), 


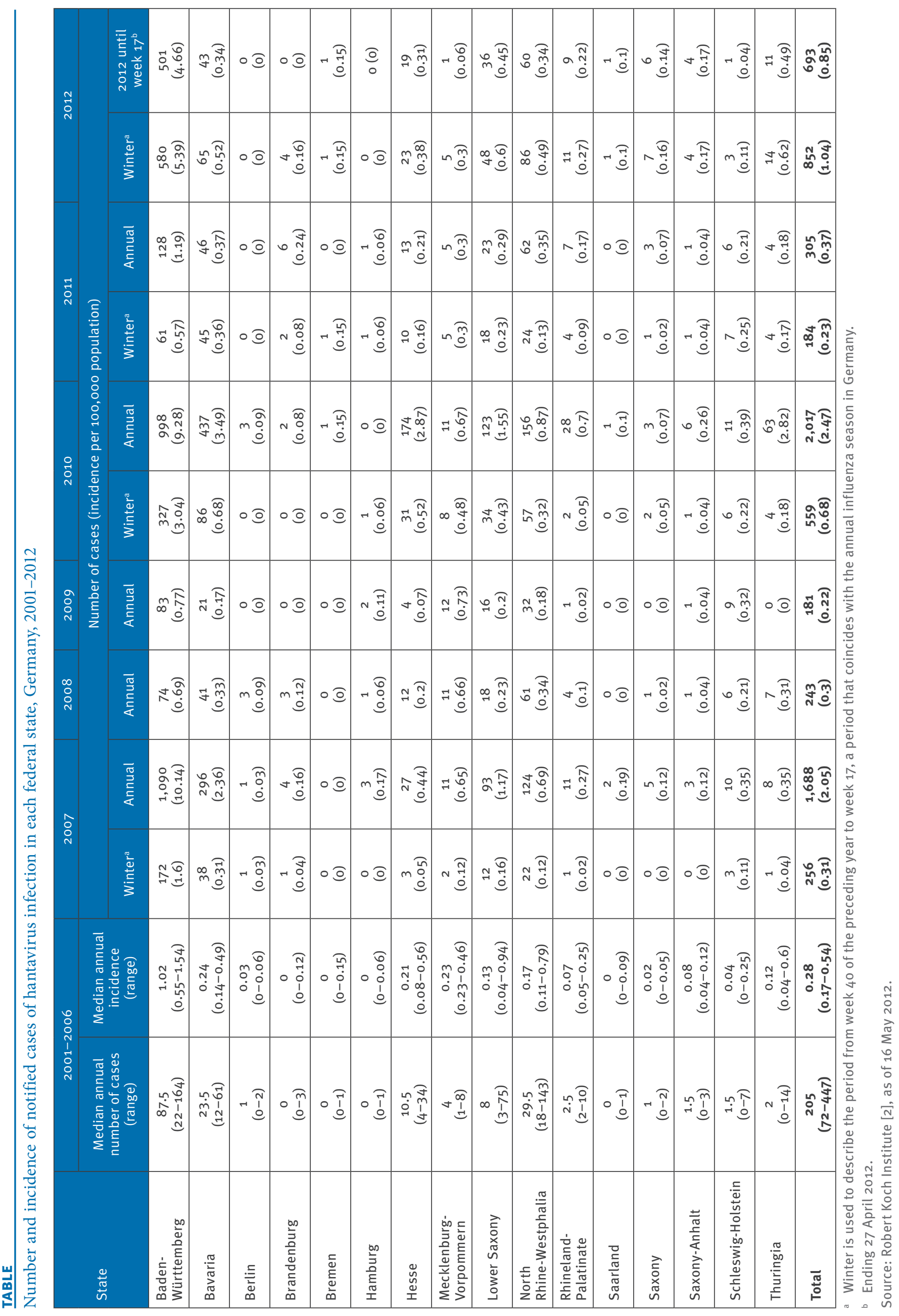




\section{FIGURE 1}

Cases of hantavirus infection by week of reporting, Baden-Württemberg, Germany, October (week 40) 2011-April (week 17) 2012 and weeks 1-39 for outbreak years 2007 and 2010, and from week 40 in 2006 and 2009 (years preceding outbreaks)

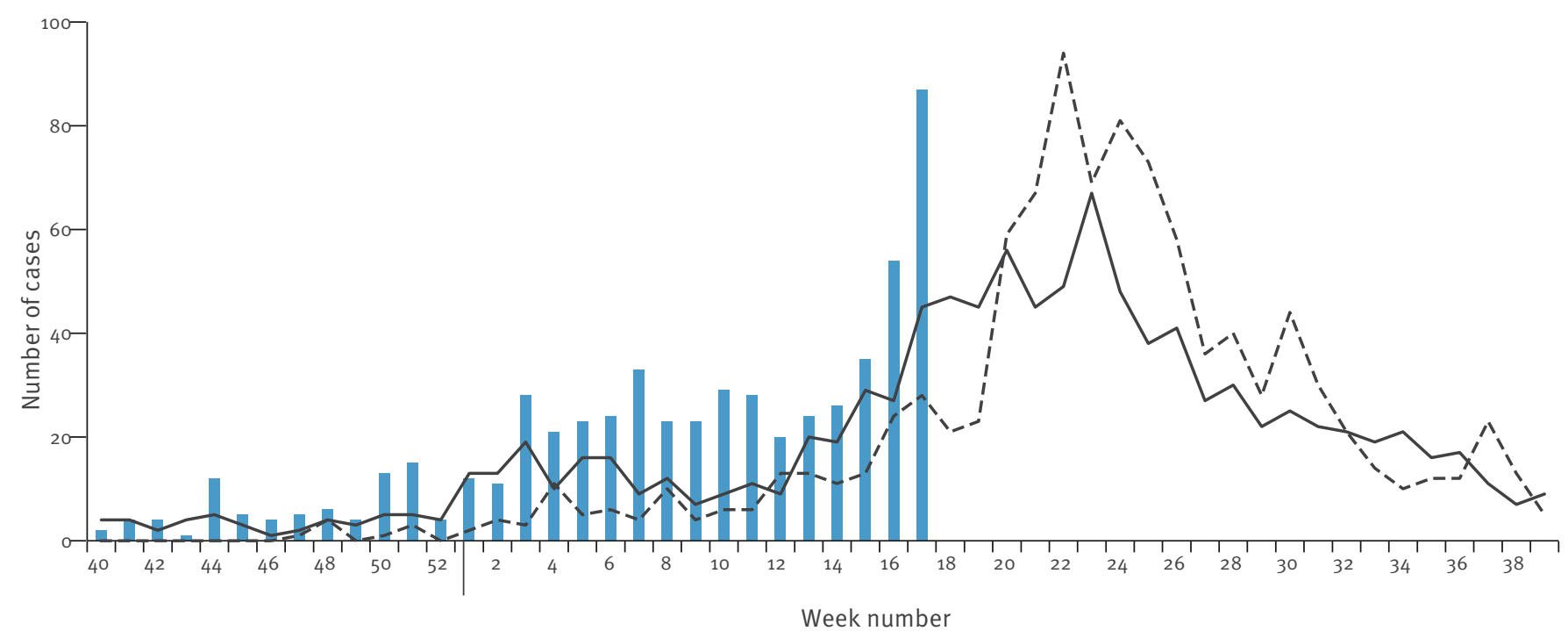

The bars show the number of cases reported during 3 October 2011 to 27 April $2012(n=580)$. The broken line shows the number of cases from week 402006 to week 392007 . The continuous line shows the number of cases from week 402009 to week 392010.

Source: Robert Koch Institute [2], as of 16 May 2012.

\section{FIGURE 2}

Geographical distribution of cases of hantavirus infection, by county and cumulative incidence, Baden-Württemberg, Germany, 3 October (reporting week 40) 2011-27 April (week 17) $2012(n=580)$
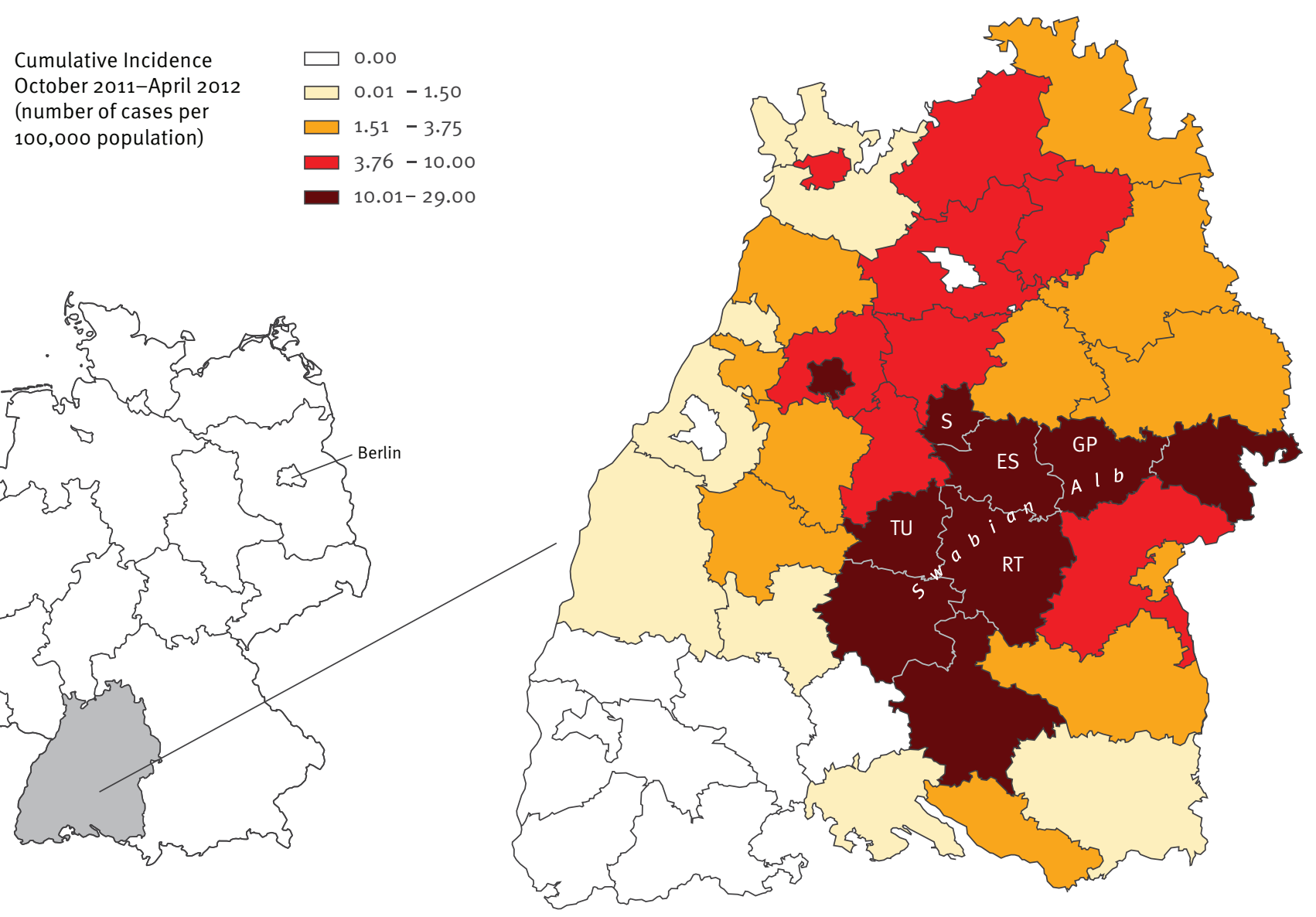

ES: Esslingen; GP: Göppingen; RT: Reutlingen; S: Stuttgart; TU: Tübingen.

Source: Robert Koch Institute [2], as of 16 May 2012. 
Esslingen ( $n=53$; incidence: 10.3 per 100,000 population), Reutlingen ( $n=62$; incidence: 22.1 per 100,000 population) and Göppingen ( $n=71$; incidence: 28.1 per 100,000 population). The last four counties are located in a hantavirus-endemic area lining the Swabian Alb, a low limestone mountain range covered by small forests and fields. Within all five counties, the cases were clustered in several municipalities (data not shown).

Of all the cases notified in Baden-Württemberg, $72 \%$ were male ( 418 of 578 cases with information on sex reported). The highest incidences were observed among persons between 20 and 59 years (Figure 3).

On the basis of preliminary data, the most common symptoms reported were fever ( $86 \%$ ), renal impairment $(75 \%)$, headache $(51 \%)$ and back pain (23\%). Some $69 \%$ of all cases were hospitalised. Where indicated (in $52 \%$ of the hospitalised cases), the median length of stay in hospital was five days (range: 1-20). No deaths were reported.

Information related to potential exposure was available for $39 \%$ of the cases. Most frequently mentioned were cutting and piling wood, spending time in a forest for leisure (hiking, hunting) or forestry work, contact with rodents or rodent excreta, especially during cleaning in barns, sheds, attics, cellars, garden houses, garages, etc.

\section{Discussion}

Previous outbreaks of hantavirus infection in BadenWürttemberg in 2007 and in 2010 started in the first months of the year and peaked from May to June [11]. The early and intense increase in case numbers since October 2011 is without precedence. Early in 2012, the public was informed of the outbreak and recommended prevention measures $[12,13]$ via media releases published state-wide on 13 January and 9 March 2012. Updated releases were also disseminated to local community-based media and physicians. However, data on the public's knowledge and the effectiveness of preventive measures against Puumala virus infections are lacking and are the subject of a separate study.

The causes for the early increase of case numbers remain unclear. Current hypotheses relate the rising incidence of Puumala virus infections to changes in the population density of bank voles, due to climatic factors [12] and possibly to the beech mast in 2011. During mast years, deciduous trees produce exceptionally high quantities of seeds, an important food source for bank voles [14]. Mast years and hantavirus outbreaks appear to be associated $[15,16]$. In BadenWürttemberg, the beech mast years of 2006 and 2009 were followed by outbreaks of human hantavirus infections in 2007 and 2010. Last year (2011) was again an exceptional mast year [17], followed by a remarkably mild winter [18]. This may have promoted winter survival and reproduction of bank vole populations.

\section{FIGURE 3}

Cumulative incidence of cases of hantavirus infection by age group and sex, Baden-Württemberg, Germany, 3 October (reporting week 40) 2011-27 April (week 17) 2012 $(\mathrm{n}=578)^{\mathrm{a}}$

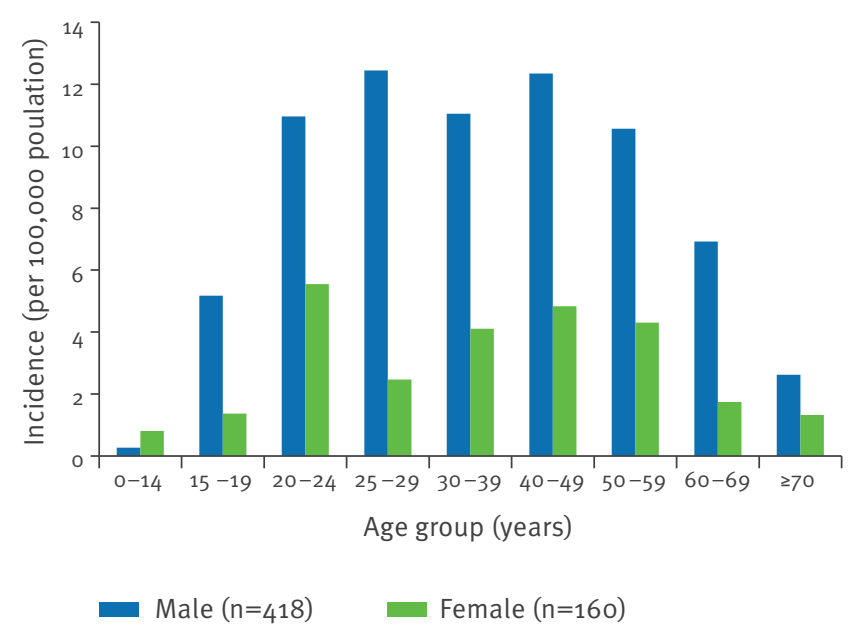

a Cases with information on sex reported.

Source: Robert Koch Institute [2], as of 16 May 2012.

Since spring 2010, the Julius Kühn-Institute (Federal Research Centre for Cultivated Plants) and FriedrichLoeffler-Institute (Federal Research Institute for Animal Health) have been conducting monitoring studies in an area of Böblingen County, Baden-Württemberg, an endemic region for hantavirus. Trapping results showed a peak mean bank vole population density of $63 \pm 46$ individuals per hectare ( $\mathrm{N} \pm$ standard error/ ha) in October 2011. In April 2012, the mean bank vole population density had increased to $76 \pm 23 /$ ha (D. Reil, unpublished data). This study indicated considerable recruitment of bank voles, either through winter reproduction or migration. Serological and molecular studies in bank voles from this monitoring site demonstrated a continuous presence of Puumala virus during 2010 and 2011 and an increased Puumala virus seroprevalence in spring 2012 (U.M. Rosenfeld, unpublished data).

We anticipate a further increase in cases numbers during summer 2012. This necessitates additional public service information on prevention measures. Further studies have been initiated to correlate habitat factors of the bank vole reservoir with human exposure and behavioural data, to better understand the reasons for this early increase in case numbers. They will also examine possibilities for preventive measures that can be more efficiently communicated - and are at the same time effective and acceptable - to the population at risk. 


\section{Acknowledgments}

The authors kindly thank Marion Muehlen (European Centre for Disease Prevention and Control (ECDC)), Pawel Stefanoff (ECDC), Christina Frank and Klaus Stark (Robert Koch Institute, Berlin) for their constructive comments in reviewing the manuscript.

\section{References}

1. Robert Koch Institute (RKI). Falldefinitionen des Robert KochInstituts zur Übermittlung von Erkrankungs- oder Todesfällen und Nachweisen von Krankheitserregern. [Case definitions for the surveillance of notifiable infectious diseases in Germany]. Berlin: RKI; 2007. [Accessed 13 May 2012]. German. Available from: http://www.rki.de/DE/Content/Infekt/IfSG/Falldefinition/ falldefinition_node.html\#doc2374714bodyText

2. Winter $\mathrm{CH}$, Brockmann SO, Piechotowski I, Alpers K, an der Heiden M, Koch J, et al. Survey and case-control study during epidemics of Puumala virus infection. Epidemiol Infect. 2009;137(10):1479-85.

3. Robert Koch Institute (RKI). SurvStat@RKI. Berlin: RKI. [Accessed 16 May 2012]. German. Available from: http://www3. rki.de/SurvStat

4. Vaheri A, Henttonen H, Voutilainen L, Mustonen J, Sironen T, Vapalahti K. Hantavirus infections in Europe and their impact on public health. Rev Med Virol. 2012. Forthcoming.

5. Schönrich G, Rang A, Lutteke N, Raftery MJ, Charbonnel N, Ulrich RG. Hantavirus-induced immunity in rodent reservoirs and humans. Immunol Rev. 2008;225:163-89.

6. Heymann DL, editor. Control of communicable diseases manual. 19th ed. Washington, DC: American Public Health Association; 2008

7. Settergren B. Clinical aspects of nephropathia epidemica (Puumala virus infection) in Europe: a review. Scand J Infect Dis. 2000;32(2):125-32.

8. Brummer-Korvenkontio $\mathrm{M}$, Vapalahti $\mathrm{O}$, Henttonen $\mathrm{H}$, Koskela P, Kuusisto P, Vaheri A. Epidemiological study of nephropathia epidemica in Finland 1989-96. Scand J Infect Dis. 1999;31(5):427-35.

9. Faber MS, Ulrich RG, Frank C, Brockmann SO, Pfaff GM, Jacob J, et al. Steep rise in notified hantavirus infections in Germany, April 2010. Euro Surveill. 2010;15(20):pii=19574. Available from: http://www.eurosurveillance.org/ViewArticle. aspx?Articleld $=19574$

10. Faensen D, Claus H, Benzler J, Ammon A, Pfoch T, Breuer T, et al.SurvNet@RKI--a multistate electronic reporting system for communicable diseases. Euro Surveill. 2006;11(4):pii=614. Available from: http://www.eurosurveillance.org/ViewArticle. aspx?Articleld $=614$

11. Robert Koch Institute. Abteilung für Infektionsepidemiologie. Hantavirus-Erkrankungen: Hinweise auf Anstieg der Fallzahlen in 2012. [Hantavirus diseases: evidence for a rise of case numbers in 2012]. Epidemiologisches Bulletin. 2012;(10):79-81. German. Available from: http://www.rki.de/ DE/Content/Infekt/EpidBull/Archiv/2012/Ausgaben/10_12. pdf;isessionid =16803D46D070418B4013497FCA4DB8 CA.2_cid238?__blob=publicationFile

12. Jacob J, Reil D, Imholt C, Rosenfeld UM, Schmidt S, Ulrich RG, et al. Hantaviren 2012. Anstieg der Infektionen möglich. [Hantaviruses 2012: a rise in the number of infections is possible]. AFZ-Der Wald. 2012;1:36-37. German. Available from: http://www.zoonosen.net/DesktopModules/Bring 2mind/DMX/ Download.aspx? Method=attachment\&Command=Core Downlo ad\&Entryld $=14816 \&$ Portalld $=24$

13. Robert Koch Institute (RKI) /Charité Universitätsmedizin Berlin /Friedrich-Loeffler-Institute (FLI) /Julius Kühn-Institute (JKI). Informationen zur Vermeidung von Hantavirus-Infektionen. [Information for the prevention of hantavirus infections]. Berlin: RKI; 2010. German. Available from: http://www.charite. de/virologie/hantapraev.pdf

14. Schwarz AC, Ranft U, Piechotowski I, Childs JE, Brockmann SO. Risk factors for human infection with Puumala virus, southwestern Germany. Emerg Infect Dis. 2009;15(7):1032-9.

15. Tersago K, Verhagen R, Servais A, Heyman P, Ducoffre G, Leirs $\mathrm{H}$. Hantavirus disease (nephropathia epidemica) in Belgium: effects of tree seed production and climate. Epidemiol Infect. 2009;137(2):250-6.

16. Clement J, Vercauteren J, Verstraeten WW, Ducoffre G, Barrios JM, Vandamme AM, et al. Relating increasing hantavirus incidences to the changing climate: the mast connection. Int J Health Geogr. 2009;8(1):1.
17. Meining S, v. Wilpert K, Augustin N, Kramer P. Waldzustandsbericht 2011 für Baden-Württemberg. [Forest status report 2011 for Baden-Württemberg]. Freiburg: Forstliche Versuchs- und Forschungsanstalt BadenWürttemberg (FVA); 2011. German. Available from: http:// www.wald-und-forst.de/waldzustandsberichte2011/ wzb_2011 bw.pdf

18. Deutscher Wetterdienst. The weather in Germany in the winter 2011/12. A wet and relatively mild winter - in spite of an exceptionally cold period at the start of February. Press release. Date of issue 08/03/2012. Available from: http:// www.dwd.de/bvbw/generator/DWDWWW/Content/Presse/ Pressemitteilungen/2012/20120308__DeutschlandwetterWin ter2011bis2012 e,templateld=raw, property=publicationFile. pdf/20120308_DeutschlandwetterWinter2011bis2012_e.pdf 